\title{
Prevalence and risk factors of erectile dysfunction among patients attending primary health care centres in Qatar
}

A. Ahmed, ${ }^{1}$ A. Alnaama, ${ }^{2}$ K. Shams ${ }^{2}$ and M. Salem ${ }^{1}$

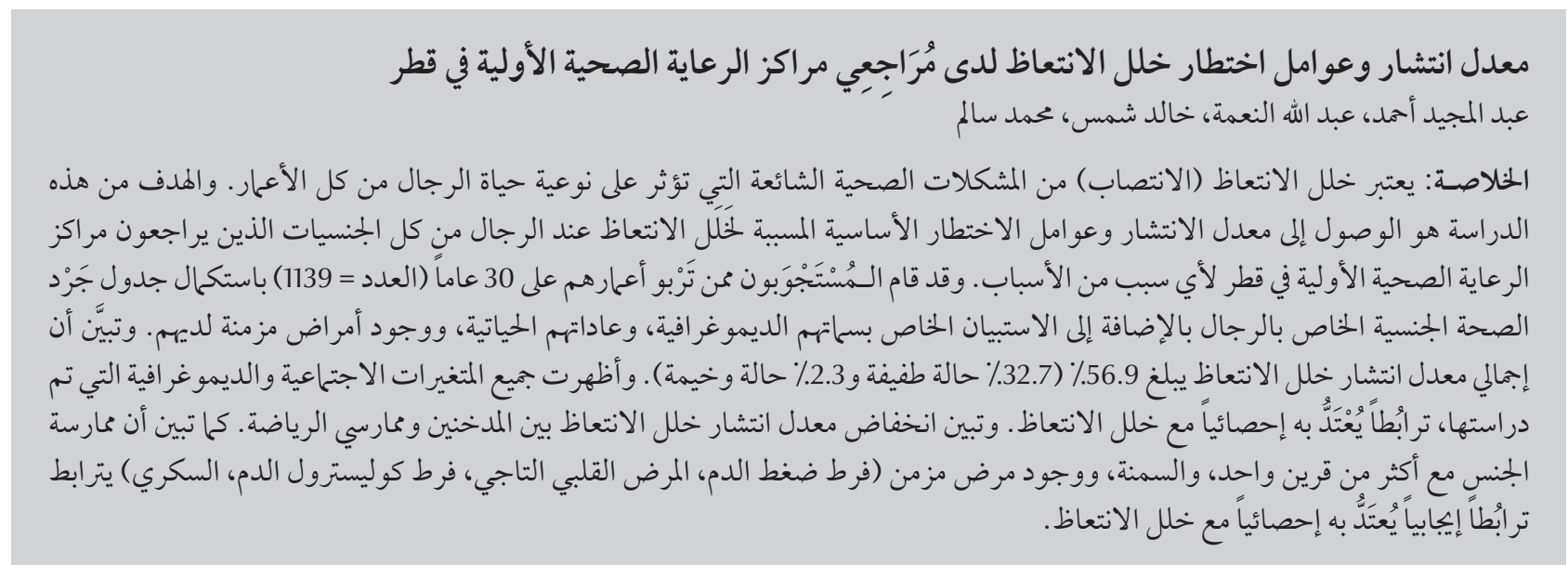

ABSTRACT Erectile dysfunction is a common health problem affecting the quality of life of men of all ages. The aim of this study was to find the prevalence of and significant risk factors for erectile dysfunction among men of all nationalities attending primary health care centres in Qatar for any reason. Respondents aged $>30$ years $(n=1139)$ completed the sexual health inventory for men plus a questionnaire about their demographic characteristics, lifestyle habits and presence of chronic diseases. The total prevalence of erectile dysfunction was $56.9 \%(32.7 \%$ mild and $2.3 \%$ severe cases). All studied sociodemographic variables showed a significant association with erectile dysfunction. A lower prevalence of erectile dysfunction was found in smokers and those who exercised. More than 1 sexual partner, obesity and having a chronic disease (hypertension, coronary heart disease, hypercholesterolaemia or diabetes mellitus) were significantly positively associated with erectile dysfunction.

Prévalence du dysfonctionnement érectile et facteurs de risque chez les patients des centres de soins de santé primaires au Qatar

RÉSUMÉ Le dysfonctionnement érectile est un problème de santé fréquent influant sur la qualité de vie des hommes de tout âge. L'objectif de la présente étude était de déterminer la prévalence du dysfonctionnement érectile et les facteurs de risque importants chez les patients des centres de soins de santé primaires au Qatar, sans distinction de motif de consultation. Les répondants âgés de plus de 30 ans $(n=1139)$ ont rempli le questionnaire SHIM sur la santé sexuelle de l'homme, plus un questionnaire sur les caractéristiques démographiques, le mode de vie et la présence de pathologies chroniques. La prévalence totale du dysfonctionnement érectile était de 56,9 \% (32,7 \% modéré et 2,3\% sévère). Toutes les variables sociodémographiques étudiées étaient significativement associées au dysfonctionnement érectile. Une prévalence plus faible du dysfonctionnement érectile a été retrouvée chez les fumeurs et les sportifs. Le fait d'avoir plus d'une partenaire sexuelle, de souffrir d'obésité ou d'une pathologie chronique (comme une hypertension, une coronaropathie, une hypercholestérolémie ou un diabète sucré) était positivement et fortement associé au dysfonctionnement érectile. 


\section{Introduction}

Erectile dysfunction is a common medical problem affecting approximately $15 \%$ of men each year [1]. Over 150 million men worldwide were estimated to have been affected by erectile dysfunction in 1995, and this is projected to rise to 320 million by 2025 [2]. Severe erectile dysfunction is an independent predictor of poor quality of life and not an indicator for comorbid diseases [2]. Erectile dysfunction may have a physiological or psychological basis, but the most common cause is thought to be related to vascular abnormalities of the penile blood supply and erectile tissue often associated with cardiovascular diseases and their risk factors $[3,4]$.

The prevalence of erectile dysfunction varies widely in studies from different countries. It was estimated to be $18.4 \%$ in men aged $\geq 20$ years in the United States [3], 49.4\% in Canada [5] and $63.6 \%$ in Hong Kong [6]. In a study in Qatar the prevalence of erectile dysfunction among Qatari patients was 66.2\% among hypertensive patients and $23.8 \%$ among non-hypertensive controls [7].

Qatar is a small developing country with population of around 1.5 million. There are 21 primary care health centres, most of them in Doha city. No previous study has investigated the prevalence of erectile dysfunction among the general population of different nationalities with different health status in Qatar. The aim of this study therefore was to estimate the prevalence of erectile dysfunction among the men of all nationalities attending primary health care (PHC) centres for any reason, and to study significant risk factors for erectile dysfunction with the aim of developing a strategic plan to prevent and control the problem.

\section{Methods}

\section{Sample}

This was a descriptive cross-sectional study conducted in 2008 in the $21 \mathrm{PHC}$ centres distributed throughout the state of Qatar. Our target population was all male patients attending all PHC centres for any reason and aged $>30$ years. The inclusion criteria were age $>$ 30 years, any nationality and agreeing to participate.

Our sample size was calculated using the Epi-info program. The expected prevalence used was $18 \%$ [3], and the worst acceptable prevalence was $15 \%$, so the sample size was 1000 patients within the $99 \%$ confidence level. Because of the sensitivity of the questions, the dropout rate was considered as $10 \%$, so the total number was 1100 patients.

We used a multistage technique to select 4 PHC centres (2 urban and 2 semi-urban) using a simple random method to ensure that the sample represented all nationalities living in Qatar. The second stage was to select about 300 patients from each centre using a systematic random method to select every 5 th male patient aged $>30$ years who was registered in the reception after taking his written consent to participate in the study. The next patient was selected if a patient refused to participate.

\section{Data collection}

Every recruited patient was given 2 questionnaires to complete. The first collected sociodemographic data (age, nationality, occupation, education, income (satisfied or not satisfied), number of children and some lifestyle and clinical information on possible risk factors for erectile dysfunction (presence of any chronic diseases and their duration, taking any medication, number of lifetime sexual partners). Data were collected on: smoking (ever smoked cigarettes), exercise (ever took exercise) and alcohol use (ever drank alcohol). Weight and height were measured to calculate body mass index (BMI). The BMI cutoffs were: overweight were 20-25 $\mathrm{kg} / \mathrm{m}^{2}$, obese $25-35 \mathrm{~kg} / \mathrm{m}^{2}$, morbidly obesity $>35 \mathrm{~kg} / \mathrm{m}^{2}$, normal $18-20 \mathrm{~kg} /$ $\mathrm{m}^{2}$, subnormal $<18 \mathrm{~kg} / \mathrm{m}^{2}$. High blood pressure was systolic/diastolic blood pressure $>140 / 90 \mathrm{mmHg}$ and diabetes mellitus was blood glucose $>126 \mathrm{mg} /$ $\mathrm{dL}$, not differentiated by type 1 or 2 .

The second questionnaire was the sexual health inventory for men (SHIM) which includes 5 questions to identify cases of erectile dysfunction and classify them into mild, moderate or severe [8]. The Arabic version of the inventory was used.

\section{Analysis}

Epi-Info, version 6 statistical package was used for data tabulation and analysis. Chi-squared and Fisher exact tests were used for testing significance. $P<0.05$ was considered significant.

\section{Results}

Of the 1139 respondents 649 had some degree of erectile dysfunction based on the SHIM scale, giving an overall crude prevalence of erectile dysfunction in this sample of $56.9 \%$. A majority were mild cases (32.7\%), while the remainder were classified as moderate (18.0\%), moderate or severe $(4.3 \%)$ or severe (2.3\%).

All of the sociodemographic factors recorded-age, nationality, education, occupation, income and number of children - were significant risk factors for erectile dysfunction (Table 1). Qatari males had the highest prevalence of erectile dysfunction (64.7\%), followed by other Asian males (60.7\%) and men of other Arab nationalities (48.0\%).

Table 2 shows the prevalence of erectile dysfunction according to some lifestyle and clinical risk factors. Males who smoked had a significantly lower prevalence of erectile dysfunction than those who did not smoke ( $48.6 \%$ versus 59.8\%) $(P=0.004)$. Men who exercised had a lower prevalence of erectile dysfunction than those who did not $(43.1 \%$ versus $69.4 \%)(P<0.001)$. Alcohol consumption was not a significant risk factor for erectile dysfunction. The prevalence of erectile dysfunction among normal 


\begin{tabular}{|c|c|c|c|c|c|c|}
\hline \multirow[t]{2}{*}{ Variable } & \multicolumn{2}{|c|}{ Erectile dysfunction } & \multicolumn{2}{|c|}{ Normal } & \multirow[t]{2}{*}{$x^{2}$} & \multirow[t]{2}{*}{$P$-value } \\
\hline & No. & $\%$ & No. & $\%$ & & \\
\hline \multicolumn{7}{|l|}{ Age (years) } \\
\hline $30-40$ & 153 & 40.7 & 223 & 59.3 & 101.33 & $<0.001$ \\
\hline$>40-50$ & 254 & 57.5 & 188 & 42.5 & & \\
\hline$>50-60$ & 179 & 71.9 & 70 & 28.1 & & \\
\hline$>60$ & 63 & 88.7 & 8 & 11.3 & & \\
\hline \multicolumn{7}{|l|}{ Nationality } \\
\hline Qatari & 110 & 64.7 & 60 & 35.3 & 9.84 & $<0.001$ \\
\hline Other Arab & 183 & 48.4 & 195 & 51.6 & & \\
\hline Asian & 349 & 60.7 & 226 & 39.3 & & \\
\hline Other & 7 & 43.8 & 9 & 56.3 & & \\
\hline \multicolumn{7}{|l|}{ Education } \\
\hline Illiterate & 174 & 64.7 & 95 & 35.3 & 8.72 & 0.012 \\
\hline Pre-university & 280 & 55.4 & 225 & 44.6 & & \\
\hline University and above & 195 & 53.4 & 170 & 46.6 & & \\
\hline \multicolumn{7}{|l|}{ Occupation } \\
\hline Unemployed & 62 & 79.5 & 16 & 20.5 & 78.17 & $<0.001$ \\
\hline Clerk & 216 & 68.8 & 98 & 31.2 & & \\
\hline Army & 12 & 34.3 & 23 & 65.7 & & \\
\hline Skilled manual & 319 & 48.0 & 345 & 52.0 & & \\
\hline Retired & 40 & 83.3 & 8 & 16.7 & & \\
\hline Income & & & & & 7.27 & 0.026 \\
\hline Satisfactory & 442 & 59.6 & 299 & 40.4 & & \\
\hline Unsatisfactory & 207 & 52.0 & 191 & 48.0 & & \\
\hline No. of children & & & & & 19.66 & $<0.001$ \\
\hline 0 & 51 & 7.9 & 51 & 10.4 & & \\
\hline $1-3$ & 302 & 46.5 & 279 & 56.9 & & \\
\hline$>3$ & 296 & 45.6 & 160 & 32.7 & & \\
\hline
\end{tabular}

weight men was $52.7 \%$, among obese men was $64.9 \%$ and among the morbidly obese was $72.4 \%(P<0.001)$. Men who had 1 sexual partner had a lower rate of erectile dysfunction than those with $>1$ partner $(55.8 \%$ versus $70.3 \%)$ $(P<0.001)$.

There were significant positive relationships between erectile dysfunction and having a chronic disease $(P<$ $0.001)$. Men suffering from hypertension, coronary heart disease, hypercholesterolaemia and diabetes mellitus had a significantly higher rate of erectile dysfunction. Those with thyroid disease, liver disease, renal disease, bronchial asthma, psychiatric disease and cerebrovascular disease also had higher rates of erectile dysfunction although the results were not statistically significant (Table 3).

\section{Discussion}

Dunn et al., in their study of the prevalence of erectile dysfunction in the general population in England, found that its prevalence was relatively high, and concluded many people would actually like help for such a problem [9]. Claro et al. also concluded that erectile dysfunction was a widespread and very common health problem affecting the quality of life of men of all ages [10].
In our study, the prevalence of erectile dysfunction in all stages was 56.9\% among men aged $>30$ years, a higher figure than $49.4 \%$ in a study in Canada among males aged $40-88$ years [ 5 ] and $51 \%$ in a study in the United States in a general medical setting [11]. However, our figure was lower than a Hong Kong study in 2001 which found the prevalence of erectile dysfunction was $63.6 \%$ [6]. Although our result was higher than most previous studies, it looks very high in comparison with a Chinese study which found that the overall prevalence of erectile dysfunction among men aged $35-74$ years was only $16.3 \%$ [12]. These differences between our result and other studies could be explained on the basis of 


\begin{tabular}{|c|c|c|c|c|c|c|}
\hline \multirow[t]{2}{*}{ Variable } & \multicolumn{2}{|c|}{ Erectile dysfunction } & \multicolumn{2}{|c|}{ Normal } & \multirow[t]{2}{*}{$x^{2}$} & \multirow[t]{2}{*}{$P$-value } \\
\hline & No. & $\%$ & No. & $\%$ & & \\
\hline Smokes & & & & & & 0.004 \\
\hline Yes & 138 & 48.6 & 146 & 51.4 & & \\
\hline No & 511 & 59.8 & 344 & 40.2 & 10.94 & \\
\hline Drinks alcohol & & & & & & 0.38 \\
\hline Yes & 30 & 66.7 & 15 & 33.3 & & \\
\hline No & 619 & 56.6 & 475 & 43.4 & 1.92 & \\
\hline Takes exercise & & & & & & $<0.001$ \\
\hline Yes & 232 & 43.1 & 306 & 56.9 & & \\
\hline No & 417 & 69.4 & 184 & 30.6 & 80.64 & \\
\hline$B M I^{a}$ & & & & & & $<0.001$ \\
\hline Subnormal & 15 & 22.1 & 53 & 77.9 & & \\
\hline Normal & 266 & 52.7 & 239 & 47.3 & & \\
\hline Overweight & 273 & 64.5 & 150 & 35.5 & & \\
\hline Obese & 74 & 64.9 & 40 & 35.1 & 5225 & \\
\hline Morbidly obese & 21 & 72.4 & 8 & 27.6 & 35.25 & \\
\hline No. of sexual partners & & & & & & \\
\hline 1 & 585 & 55.8 & 463 & 44.2 & & م 01 \\
\hline$>1$ & 64 & 70.3 & 27 & 29.7 & 9.23 & 0.01 \\
\hline Surgery or vertebral column tr & & & & & & \\
\hline Yes & 29 & 59.2 & 20 & 40.8 & & 075 \\
\hline No & 620 & 56.9 & 470 & 43.1 & 0.1 & נית. \\
\hline $\begin{array}{l}\text { Using medication for erectile } \\
\text { dysfunction }\end{array}$ & & & & & & $<0.001$ \\
\hline Yes & 84 & 85.7 & 14 & 14.3 & & \\
\hline No & 565 & 54.3 & 476 & 45.7 & 36.06 & \\
\hline
\end{tabular}

${ }^{a}$ Subnormal $<18 \mathrm{~kg} / \mathrm{m}^{2}$, normal $18-20 \mathrm{~kg} / \mathrm{m}^{2}$, overweight $20-25 \mathrm{~kg} / \mathrm{m}^{2}$, obese $25-35 \mathrm{~kg} / \mathrm{m}^{2}$, morbidly obesity $>35 \mathrm{~kg} / \mathrm{m}^{2}$. $B M I=$ body mass index.

difference in culture and methodologies used including difference in the sample sizes and sample techniques.

The prevalence of different degrees of erectile dysfunction found in the present study (32.7\% mild, $18.0 \%$ moderate, $4.3 \%$ moderate to severe and $2.3 \%$ severe) can be compared with another study in the United States of 1290 individuals in which $27 \%$ of the sample population were suffering from mild erectile dysfunction, $17 \%$ moderate and $10 \%$ severe [13]. The difference could be due to different population age groups (they started from 40 years or more) and different population cultures and sociodemographic risk factors.
Regarding sociodemographic risk factors, we found that age, nationality, occupation, education level, number of children and satisfaction with income all showed significant differences between men suffering from erectile dysfunction and those who did not. This result is supported by many studies $[7,9-11,14,15]$. Surprisingly, Qatari males showed the highest prevalence of erectile dysfunction (64.7\%) compared with other nationalities. Such a high prevalence might be explained by a lack of exercise due to the high income and urbanized lifestyle in Qatar in addition to unhealthy nutrition resulting in obesity and other chronic diseases. The high prevalence in a Hong Kong study (63.6\%) [6] agrees with our result for Asian males (60.7\%). A study in Brazil found that there was no statistical difference in the rate of erectile dysfunction between men of different salary levels, which could be explained by the narrow salary difference among their population sample in comparison with the big differences in income among the population of Gulf countries [10].

Taking exercise was significantly associated with erectile dysfunction, as found by some other studies $[1,3,10,12,14]$. On the other hand, the finding that smokers had a lower prevalence of erectile dysfunction than non-smokers contrasts with the findings of these studies. This result raises 


\begin{tabular}{|c|c|c|c|c|c|c|}
\hline \multirow[t]{2}{*}{ Variable } & \multicolumn{2}{|c|}{ Erectile dysfunction } & \multicolumn{2}{|c|}{ Normal } & \multirow[t]{2}{*}{$x^{2}$} & \multirow[t]{2}{*}{$P$-value } \\
\hline & No. & $\%$ & No. & $\%$ & & \\
\hline \multicolumn{7}{|c|}{ Chronic disease } \\
\hline Yes & 402 & 74.6 & 137 & 25.4 & & \\
\hline No & 247 & 41.2 & 353 & 58.8 & 128.03 & $<0.001$ \\
\hline \multicolumn{7}{|c|}{ Hypertension $^{a}$} \\
\hline Yes & 247 & 74.6 & 84 & 25.4 & & \\
\hline No & 402 & 49.8 & 406 & 50.2 & 58.9 & $<0.001$ \\
\hline \multicolumn{7}{|c|}{ Coronary heart disease } \\
\hline Yes & 19 & 90.5 & 2 & 9.5 & & \\
\hline No & 630 & 56.4 & 488 & 43.6 & $9.7^{c}$ & 0.002 \\
\hline \multicolumn{7}{|c|}{ Diabetes mellitus ${ }^{b}$} \\
\hline Yes & 275 & 82.6 & 58 & 17.4 & & \\
\hline No & 374 & 46.4 & 432 & 53.6 & 15.32 & $<0.001$ \\
\hline \multicolumn{7}{|c|}{ Thyroid disease } \\
\hline Yes & 8 & 72.7 & 3 & 27.2 & & \\
\hline No & 641 & 56.8 & 487 & 43.2 & $1.12^{\mathrm{c}}$ & 0.29 \\
\hline \multicolumn{7}{|c|}{ Hypercholesterolaemia } \\
\hline Yes & 64 & 97.0 & 2 & 3.0 & & \\
\hline No & 585 & 55.5 & 470 & 44.5 & 13.58 & $<0.001$ \\
\hline \multicolumn{7}{|c|}{ Liver disease } \\
\hline Yes & 4 & 66.7 & 2 & 33.4 & & \\
\hline No & 645 & 56.9 & 488 & 43.1 & $0.23^{c}$ & 0.12 \\
\hline \multicolumn{7}{|c|}{ Renal disease } \\
\hline Yes & 6 & 85.7 & 1 & 14.3 & & \\
\hline No & 643 & 56.8 & 489 & 43.2 & $2.36^{c}$ & 0.12 \\
\hline \multicolumn{7}{|c|}{ Bronchial asthma } \\
\hline Yes & 22 & 64.7 & 12 & 35.3 & & \\
\hline No & 627 & 56.7 & 478 & 43.3 & 0.84 & 0.35 \\
\hline \multicolumn{7}{|c|}{ Psychiatric disease } \\
\hline Yes & 3 & 75.0 & 1 & 25.0 & & \\
\hline No & 646 & 56.9 & 489 & 43.1 & $0.53^{c}$ & 0.46 \\
\hline \multicolumn{7}{|c|}{ Peripheral vascular disease } \\
\hline Yes & 2 & 66.7 & 1 & 33.4 & & \\
\hline No & 647 & 57.0 & 489 & 43.0 & $0.53^{c}$ & 0.46 \\
\hline \multicolumn{7}{|c|}{ Cerebrovascular disease } \\
\hline Yes & 1 & 100.0 & 0 & 0 & & \\
\hline No & 648 & 48.9 & 490 & 51.1 & $0.75^{c}$ & 0.38 \\
\hline
\end{tabular}

${ }^{a}$ High blood pressure $=$ systolic $/$ diastolic blood pressure $>140 / 90 \mathrm{mmHg}$.

${ }^{b}$ Diabetes mellitus $=$ blood glucose $>126 \mathrm{mg} / \mathrm{dL}$, not differentiated by type 1 or 2 .

cFisher exact test.

a question about the use of tobacco to relieve stress, which is a common problem among the expatriate population due to the high workload and insecure employment. Alcohol consumption was not a significant factor in erectile dysfunction, a finding which disagrees with a study in the United States showing a higher prevalence of erectile dysfunction among men who drank alcohol than those who did not [16]. The rate of obesity was significantly different comparing men with and without erectile dysfunction in our study. Burnett et al. in the United States [3] and Hunter Wessells et al. in China [17] also found that obesity was a significant risk factor for erectile dysfunction. Having more 
than 1 sexual partner was also a significant risk factor in our study.

We found that the prevalence of erectile dysfunction was significantly higher in men suffering from certain chronic diseases-hypertension, hypercholesterolaemia, coronary artery diseases and diabetes mellitus - than those without. These findings were expected, as they correspond with those of other researchers. Fouroutan et al. supported the relation between erectile dysfunction and both coronary artery diseases and hypercholesterolaemia [1]. Many other studies agree on this finding $[3,5,7,12,18,19]$. For diabetes, a number of previous studies showed it to be a major risk factor for erectile dysfunction which increased with increasing duration of disease $[5-7,11,15,18,20,21]$. Although erectile dysfunction was also more common in men suffering from the other chronic diseases studied -thyroid diseases, liver diseases, renal diseases, cerebrovascular diseases, peripheral vascular diseases, bronchial asthma and psychiatric diseases - the differences were not significant. Rosen et al. concluded that erectile dysfunction was associated with increased age, diabetes, kidney disease, atherosclerosis, vascular disease and depression [22].
This difference was probably due to smaller size of our sample of males suffering from such conditions.

\section{Conclusion}

The high prevalence of erectile dysfunction among men attending PHC centres in Qatar is a concern. Health policy-makers need to consider including training of health personnel to consider the relevant risk factors during the physical, social and psychological diagnosis of different age and ethnic groups.

\section{References}

1. Johannes $\mathrm{CB}$ et al. Incidence of erectile dysfunction in men 40 to 69 years old: longitudinal results from the Massachusetts male aging study. Journal of Urology. 2000, 163:460-463.

2. Abolfotouh MA, Al-Helali NS. Effect of erectile dysfunction on quality of life. Eastern Mediterranean Health Journal, 2001, 7(3):510-518.

3. Selvin E, Burnett AL, Platz EA. Prevalence and risk factors for erectile dysfunction in the US. American Journal of Medicine, 2007, 120:151-157.

4. Jeremy JY et al. Effects of sildenafil, a type-5 cGMP phosphodiasterase inhibitor, and papaverine on cyclic GMP and cyclic AMP levels in the rabbit corpus cavernosum in vitro. British Journal of Urology, 1997, 79(6):958-963.

5. Grover SA et al. The prevalence of erectile dysfunction in the primary care setting. Archives of Internal Medicine, 2007, 166:213-219.

6. Siu SC et al. Prevalence of and risk factors for erectile dysfunction in Hong Kong diabetic patients. Diabetic Medicine, 2001, 18:732-738.

7. Bener A et al. Prevalence of erectile dysfunction among hypertensive and nonhypertensive Qatari men. Medicina (Kaunas, Lithuania), 2007, 43:870-878.

8. Rosen RC et al. Development and evaluation of an abridged, 5 -item version of the international index of erectile dysfunction (IIEF-5) as a diagnostic tool for erectile dysfunction. International Journal of Impotence Research, 1999, 11:319-326.

9. Dunn KM, Croft PR, Hackett GI. Sexual problems: a study of the prevalence and need for health care in the general population. Family Practice, 1998, 15(6):519-524.

10. De Almeida Claro J et al. Could a rural life style decrease the prevalence of erectile dysfunction? BJU International, 2006, 99:127-129.

11. Kantor J et al. Prevalence of erectile dysfunction and active depression: an analytic cross-sectional study of general medical patients. American Journal of Epidemiology, 2002, 156:10351042.
12. May M et al. Erectile dysfunction, discrepancy between high prevalence and low utilization of treatment options. BJU International, 2007, 100:1110-1115.

13. Johannes $\mathrm{CB}$ et al. Incidence of erectile dysfunction in men 40 to 69 years old: longitudinal results from the Massachusetts male aging study. Journal of Urology, 2000, 163:460-463.

14. Tan HM et al. Prevalence and correlates of erectile dysfunction (ED) and treatment seeking for ED in Asian Men: the Asian Men's Attitudes to Life Events and Sexuality (MALES) study. Journal of Sexual Medicine, 2007, 4:1582-1592.

15. Wessells $\mathrm{H}$ et al. Erectile dysfunction. Journal of Urology, 2007, 177:1675-1681.

16. Francis ME et al. The contribution of common medical conditions and drug exposure to erectile dysfunction in adult males. Journal of Urology, 2007, 178:591-596.

17. He J et al. Cigarette smoking and erectile dysfunction among Chinese men. American Journal of Epidemiology, 2007, 166:803-809.

18. Bacon CG et al. Association of type and duration of diabetes with erectile dysfunction in a large cohort of men. Diabetes Care, 2002, 25(8):1458-1463.

19. Brookes ST et al. Relationship between lower urinary tract symptoms and erectile dysfunction: results from the Boston Area Community Health Survey. Journal of Urology, 2008, 179:250-255.

20. Al-Hunayan A et al. The prevalence and predictors of erectile dysfunction in men with newly diagnosed with type 2 diabetes mellitus. BJU International, 2007, 99:130-134.

21. Eardley I et al. The multinational Men's Attitudes to Life Events and Sexuality study: the influence of diabetes on self-reported erectile function, attitudes and treatment-seeking patterns in men with erectile dysfunction. International Journal of Clinical Practice, 2007, 61(9):1446-1453.

22. Rosen RC et al. The multinational Men's Attitudes to Life Events and Sexuality (MALES) study: I. Prevalence of erectile dysfunction and related health concerns in the general population. Current Medical Research and Opinion, 2004, 20:607-617. 